\title{
Analysis of wind impact on emission of selected exhaust compounds in jet engines of a business jet aircraft in cruise phase
}

\begin{abstract}
Among the most important problems currently faced by air transport, we can distinguish the adverse impact of aircrafts on the natural environment, as well as the rising costs of transport. One of the possibilities to improve this situation is better adjustment of aircraft characteristics to the performed transport tasks, taking into account all the requirements and limitations that exist in air traffic and the adverse impact of air transport on the natural environment. It is reflected in the research tasks conducted under the SESAR program. The aspiration to minimize the adverse impact of aircrafts on the environment is executed, among others, through determining such trajectories that are characterized by minimal fuel consumption or minimal emission of harmful substances in the engines exhausts. These goals are corresponding with the research conducted and described in the paper. The main aim of the work was to analyse the impact of wind speed and direction on the emission of harmful substances of a jet aircraft performing a flight on a given route. For research purposes, the route between two Polish cities Gdansk and Rzeszow was considered. The distance between the two airports was divided into sections for which wind direction and strength were determined (read from the windy.com website). Next, the aircraft performance was determined and the fuel consumption and the amount of harmful compounds $\left(\mathrm{CO}_{2}, \mathrm{NO}_{x}, \mathrm{CO}\right.$ and $\left.\mathrm{HC}\right)$, emitted in the engines exhausts were determined for the route from Gdansk to Rzeszow (under favourable wind conditions) and on the return route - from Rzeszow to Gdansk (under unfavourable wind conditions). For comparative purposes, emission of these substances for windless conditions was also determined. The results are presented in tables and depicted in the graph, as well as discussed in the conclusions of the paper.
\end{abstract}

Key words: jet engine, emission, exhausts, fuel consumption, cruise phase, ATM, SESAR

\section{Introduction}

As a result of the intensive development of air transport, there is observed a continuous increase in emissions of harmful substances in jet engines exhausts, influencing the air quality and deepening the greenhouse effect, which in turn leads to irreversible global climate change. In 1988 there was established the Intergovernmental Panel on Climate Change (IPCC) to monitor negative climate changes resulting from the economic activities $[1,8]$.

According to the IPCC reports, if preventive measures are not taken, the temperature in the current century will increase more than in the last 10,000 years, which in turn will affect the entire ecosystem. To increase environmental protection, the United Nations Framework Convention on Climate Change (UNFCCC) was adopted, under which the Kyoto Protocol was signed. This is the most important agreement in the field of climate protection, the objective of which is to reduce greenhouse gas emissions through proecological activities undertaken mainly in highly developed countries. The European Union is a party to the Kyoto Protocol with the main objective of reducing emissions in all the EU countries (reduction of greenhouse gas emissions by $8 \%$ compared to 1990 levels), and individual emission targets for each EU Member State. The basis of the EU climate policy is the European Climate Change Program (ECCP), initiated in 2000, which is a combination of voluntary activities, good practices, market mechanisms and information programs.

The activities aimed at reducing the negative impact of air transport and aviation industry on the environment match the above goals. They are reflected in two largest aviation programs implemented by the European Union.
The first one is SESAR 2020 [12], which is a continuation of the SESAR program, while the second one is the Clean Sky 2 [3], which is a continuation of the Clean Sky program. The SESAR 2020 program focuses on searching for new solutions in the field of Air Traffic Control (ATC) and Air Traffic Management (ATM). It is assumed that the solutions developed under this program will lead to a tenfold increase in the level of safety, a triple increase in airspace capacity, a 50\% reduction in air traffic management costs and a 10\% reduction in the negative impact of air transport on the natural environment. The Clean Sky 2 program focuses on developing new technical and technological solutions that are more environmentally friendly (new aircraft, new power units and on-board systems, etc.).

One of the ways to reduce the negative impact of aircraft on the natural environment is the appropriate shaping of flight paths to minimize the emission of harmful substances. This requires proper flight planning, taking into account the limitations resulting from the airspace structure and applicable regulations, as well as the current weather conditions. The weather is one of the most important factors affecting the fuel consumption, flight time and costs. The algorithm determining the fuel consumption, flight time and finally aircraft emission, at the stage of flight planning should be based on the best weather forecasts. This will enable to minimize uncertainty of the parameters and optimize the flight path taking into account the most favourable conditions for a given flight. In addition to typical parameters, such as pressure and air density, special attention must be paid to the correct determination of the temperature, speed and wind direction. The speed of sound depends on the temperature, which allows to determine 
correctly the Mach number for an aircraft flying at a given true airspeed (TAS). The wind speed and direction influence the aircraft groundspeed (VOG).

Planning a flight that minimizes emissions or fuel consumption is a difficult and demanding task, due to the complexity of the conditions that have to be taken into account (airspace structure, restrictions, location of prohibited zones, traffic conditions and weather forecast). It can be done only with the use of an appropriate computing system. The flight planning system must include appropriate computing models: aircraft, airspace, flight path, air traffic and weather [9]. In addition, it must have access to current weather conditions and information on current and planned air traffic and the airspace structure. All these elements will be used by the appropriate computation algorithm, which will be able to determine the optimal flight profile for a given criterion (cost, fuel consumption, emission of harmful compounds in the exhausts, etc.), taking into account the current flight conditions and existing restrictions and boundaries.

The development of a flight planning algorithm for different flight modes, i.e. on fixed routes or in FRA (Free Route Airspace), is one of the research and development tasks performed by the authors of the paper under the SESAR 2020 program. One of the optimization criterion is the emission of harmful compounds in the exhausts.

In the process of developing computational models that will determine the optimal aircraft's trajectory, it is very important to know how sensitive is the solution to the change of the optimization parameters or the change of external parameters. Based on this information, it will be possible to select the parameters of the used models, which will allow to obtain results with satisfactory accuracy, with the lowest calculation costs. It will also enable to determine appropriate weights at the edges of the graph modelling the airspace, appropriate for the implementation of the assumed task objectives. The purpose of the presented work is to determine the impact of wind speed and direction on the emission of harmful compounds in the aircrafts engines on a fixed route. It will enable to determine an aircraft trajectory in terms of the minimization of emissions resulting from fuel combustion by a jet aircraft's engines and determine the sensitivity of the solution to the impact of external conditions.

\section{Problem statement and research methodology}

This paper describes the impact of wind on the emissions of pollutants in the exhausts of a passenger aircraft, on the example of a business jet aircraft (Gulfstream IV, equipped with two Rolls Royce Tay $611 \mathrm{C}$ engines) on the exemplary route. The presented research methodology is universal and can be applied to any other jet aircraft - passenger and transport one. The research was focused only on the cruise phase, because it is usually the longest part of the journey. For most commercial passenger aircrafts, most of the fuel is consumed in this phase of flight. It takes place between the stages of ascent and descent. It ends when the plane approaches the destination, and the descent phase begins, and the plane prepares to land. During a cruise phase, for operational reasons or due to Air Traffic Control (ATC) instructions, planes can change a given flight level - they can climb to a higher level or descent to a lower one. During very long flights, planes are able to fly higher when the value of the thrust required for flight decreases, which results from the decreasing weight of the aircraft along with the decreasing weight of fuel consumed during the flight. Usually, pilots ask ATC to allow them to fly at the optimum flight level for the aircraft they operate. This optimal level of flight depends, for example, on the type of aircraft, its operating mass and flight length. ATC generally accepts this request if it does not compromise safety.

In the research there was adopted an exemplary mission of the aircraft on the route between two Polish cities Gdansk and Rzeszow, for which the cruise phase was 384 $\mathrm{km}$ long. In this phase, the cruising speed was assumed to be $0.8 \mathrm{Ma}$ at the altitude of $10,000 \mathrm{~m}$, as shown in Fig. 1 .

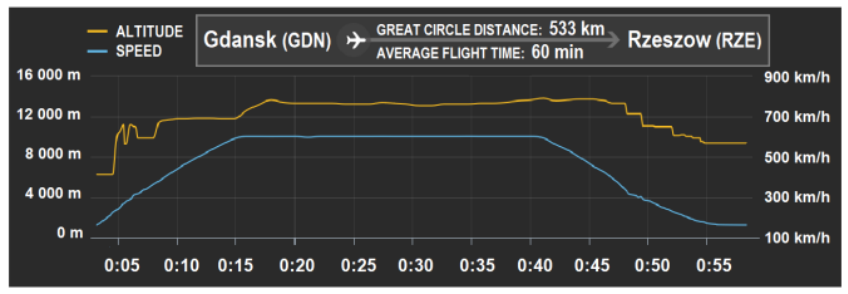

Fig. 1. Trajectory of Gulfstream IV, equipped with two Rolls Royce Tay $611 \mathrm{C}$ engines (based on [5])

Assuming no wind conditions, the aircraft reaches a cruising altitude of $10,000 \mathrm{~m} 15$ minutes after the take-off and a relatively constant speed of $0.8 \mathrm{Ma}$ (about $860 \mathrm{~km} / \mathrm{h}$ ). It descends for the last 18 minutes of the flight. In the analysed case, the research on $\mathrm{NO}_{\mathrm{x}}, \mathrm{HC}, \mathrm{CO}$ and $\mathrm{CO}_{2}$ emission concerns 27 minutes of a steady flight (from 15 th to 42 nd minute of the flight), which corresponds to the flight trajectory of $384 \mathrm{~km}$. However, in the research it was important to study the impact of wind on emission, so the time of flight on the route shown in Fig. 1 will change (shorten or lengthen).

On the basis of real meteorological data obtained via windy.com, the wind distribution on the considered route was analysed on the altitude from $10,000 \mathrm{~m}$, taking into account its direction and velocity. The distance covered by the aircraft in the cruise phase was divided into 16 sections of the length of $24 \mathrm{~km}$ each, as shown in Fig. 2.

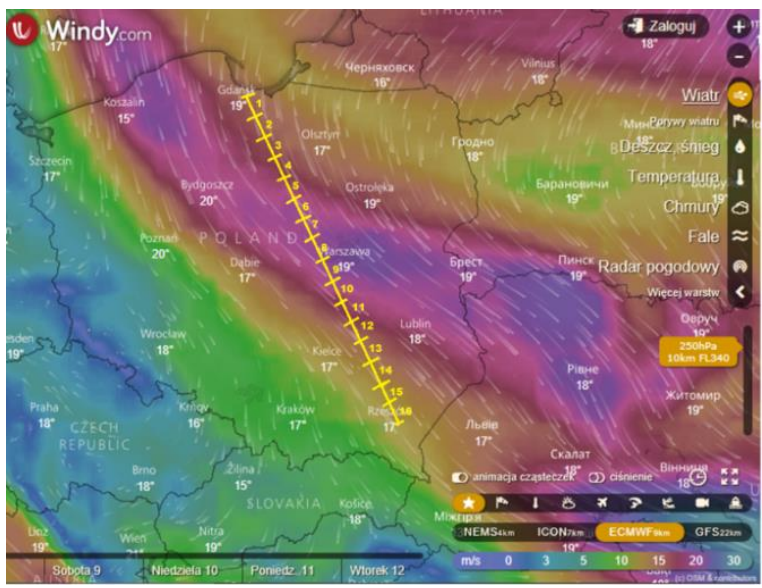

Fig. 2. Map of meteorological conditions (wind direction and velocity) at the time of conducted research on the trajectory of Gulfstream between Gdansk and Rzeszow at the altitude of $10,000 \mathrm{~m}$ (based on [10]) 
Based on meteorological data, for each of these sections the wind velocity and its direction in relation to the flight trajectory were determined. The component of wind velocity $\mathrm{V}_{\mathrm{x}}$, affecting the velocity of the aircraft's flight over ground VOG was also determined (Fig. 3).

Depending on the wind direction (from the head or the tail of the aircraft), the component of the wind velocity $V_{x}$ will be added or subtracted from the velocity vector of the aircraft. By dividing the obtained value by the length of the route that the aircraft covered in the cruise phase, the flight time is computed, which is required to determine the emission of pollutants in the exhausts.

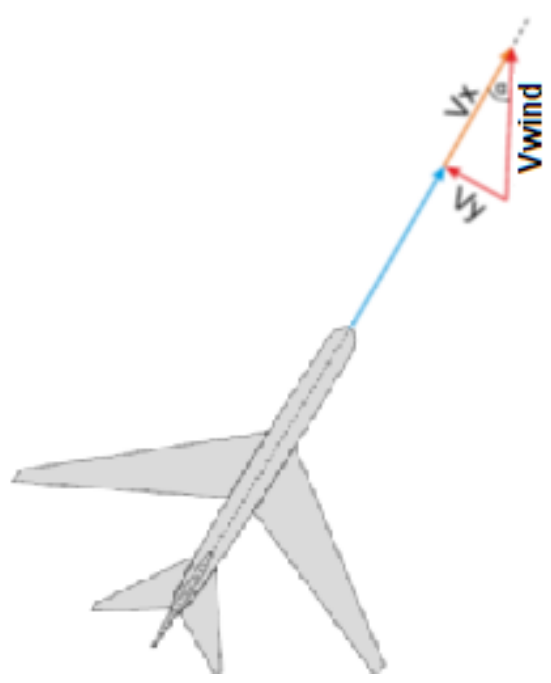

Fig. 3. Distribution of a wind vector $\mathrm{V}_{\text {wind }}$ on $\mathrm{V}_{\mathrm{x}}$ and $\mathrm{V}_{\mathrm{y}}$ components

$$
\mathrm{V}_{\mathrm{x}}=\mathrm{V}_{\text {wind }} \cdot \cos \alpha_{\text {wind }}
$$

where: $V_{x}$ - axial component of wind velocity, $V_{\text {wind }}-$ wind velocity, $\alpha_{\text {wind }}-$ angle between the velocity of the aircraft and the direction of the wind,

$$
\mathrm{V}_{\mathrm{OG}}=\mathrm{V}_{\text {flight }} \mp \mathrm{V}_{\mathrm{x}}
$$

where: $\mathrm{V}_{\mathrm{OG}}$ - velocity of the aircraft over ground, $\mathrm{V}_{\text {flight }}$ velocity of the aircraft relative to air,

$$
\mathrm{t}=\frac{\mathrm{L}}{\mathrm{V}_{\mathrm{OG}}}
$$

where: $\mathrm{t}$ - flight time of the aircraft in the cruise phase, $\mathrm{L}-$ distance covered by the plane in the cruise phase.

\section{Analysis of the results of conducted research}

The purpose of many studies and projects aimed at increasing the efficiency of using air transport is to optimize the trajectory of the flight.

The flight path is implemented through fragments of the airspace. The optimal trajectory will run through fragments of space with the best parameters defined for the flight being performed. In this work, the focus will be on optimizing the trajectory of the flight in terms of minimizing emissions of pollutants in the jet engines exhausts. The ambient conditions in particular fragments of the airspace were taken into account (wind velocity and wind directions at different flight levels). The results of these computations are given in Table 1 .
Table 1. Data on the wind speed and its wind direction relative to the trajectory of the flight

\begin{tabular}{|c|c|c|}
\hline Section number & $\mathrm{V}_{\text {wind }}[\mathrm{m} / \mathrm{s}]$ & $\left.\alpha{ }^{\circ}\right]$ \\
\hline 1 & 16 & 25 \\
\hline 2 & 16 & 30 \\
\hline 3 & 16 & 20 \\
\hline 4 & 16 & 10 \\
\hline 5 & 20 & 10 \\
\hline 6 & 20 & 20 \\
\hline 7 & 20 & 30 \\
\hline 8 & 20 & 20 \\
\hline 9 & 20 & 20 \\
\hline 10 & 18 & 20 \\
\hline 11 & 18 & 20 \\
\hline 12 & 16 & 30 \\
\hline 13 & 16 & 35 \\
\hline 14 & 18 & 35 \\
\hline 15 & 15 & 35 \\
\hline 16 & 12 & \\
\hline
\end{tabular}

To perform a flight at a given altitude at a given velocity, a given thrust is required. This thrust can be determined using the following formulas (4)-(6). For the given flight parameters (altitude and flight speed) and aircraft parameters (mass, weight and lifting surface), the drag and lift coefficients can be assigned. With these coefficients $\left(C_{z}\right.$ and $\mathrm{C}_{\mathrm{x}}$ ), it is possible to determine the power and thrust required for the flight [5]:

$$
\begin{gathered}
\mathrm{N}_{\mathrm{n}}=\frac{\mathrm{C}_{\mathrm{x}}}{\mathrm{C}_{\mathrm{z}}} \cdot \mathrm{Q} \cdot \mathrm{V} \\
\mathrm{P}_{\mathrm{n}}=\frac{\mathrm{N}_{\mathrm{n}}}{\mathrm{V}}
\end{gathered}
$$

where: $N_{n}-$ power required for the flight, $P_{n}-$ thrust required for the flight, $\mathrm{C}_{\mathrm{x}}-$ drag coefficient, $\mathrm{C}_{\mathrm{z}}-$ lift coefficient (depend on mass and velocity airplane), $\mathrm{V}$ - flight velocity, Q - airplane weight determined from the formula:

$$
\mathrm{Q}=\mathrm{m} \cdot \mathrm{g}
$$

where: $\mathrm{m}$ - mass of the plane, $\mathrm{g}$ - acceleration of gravity.

For the computed value of thrust required for the flight there ca be read the appropriate value of the engine thrust from the altitude-speed characteristics to ensure safe flight parameters and also the specific fuel consumption corresponding to that thrust value. Based on available data bases, e.g. [6], for this value of the thrust, it is possible then to determine the $\mathrm{CO}_{2}, \mathrm{NO}_{\mathrm{x}}, \mathrm{HC}, \mathrm{CO}$ emission indexes (EI), which constitutes the first step in further computations of emissions of these compounds in jet engines exhausts. Emission indexes depend on the design of the engine, its load and the flight altitude. Knowing the emission indexes, it is possible to determine the emission of $\mathrm{CO}, \mathrm{NO}_{\mathrm{x}}$ and $\mathrm{HC}$ on a given section of the aircraft's cruise phase. For this reason the formulas (7)-(9) can be applied [11].

$$
\begin{array}{rlr}
\mathrm{E}_{\mathrm{NOx}} & =\mathrm{EI}_{\mathrm{NOx}} \cdot 10^{-3} \cdot \mathrm{K} \cdot \mathrm{SFC} \cdot \mathrm{t} \cdot \mathrm{l} & {[\mathrm{kg}]} \\
\mathrm{E}_{\mathrm{CO}} & =\mathrm{EI}_{\mathrm{CO}} \cdot 10^{-3} \cdot \mathrm{K} \cdot \mathrm{SFC} \cdot \mathrm{t} \cdot \mathrm{l} & {[\mathrm{kg}]} \\
\mathrm{E}_{\mathrm{HC}} & =\mathrm{EI}_{\mathrm{HC}} \cdot 10^{-3} \cdot \mathrm{K} \cdot \mathrm{SFC} \cdot \mathrm{t} \cdot \mathrm{l} & {[\mathrm{kg}]}
\end{array}
$$

where: $\mathrm{E}_{\mathrm{NOx}} / \mathrm{E}_{\mathrm{CO}} / \mathrm{E}_{\mathrm{HC}}-$ emission of particular compounds in exhausts $[\mathrm{kg}], \mathrm{EI}_{\mathrm{NOx}} / \mathrm{EI}_{\mathrm{CO}} / \mathrm{EI}_{\mathrm{HC}}-$ emission factors for particular substances, depended on the type of engine and 
the range of its run $[\mathrm{g} / \mathrm{kg}], \mathrm{K}$ - engine thrust [N], SFC specific fuel consumption $[\mathrm{kg} /(\mathrm{N} \cdot \mathrm{h})], \mathrm{t}$ - engine run time at a given thrust $[\mathrm{h}], 1-$ number of engines.

Emission of $\mathrm{CO}_{2}$ depends only on fuel consumption. The formula of the carbon dioxide emission is as follows [11]:

$$
\mathrm{E}_{\mathrm{CO}_{2}}=3.15 \cdot \mathrm{K} \cdot \mathrm{SFC} \cdot \mathrm{t} \cdot \mathrm{l} \quad[\mathrm{kg}]
$$

The emission of $\mathrm{NO}_{\mathrm{x}}, \mathrm{CO}, \mathrm{HC}$ and $\mathrm{CO}_{2}$ in the exhausts of Gulfstream IV in each section of the cruise phase of the journey from Gdansk to Rzeszow for the assumed flight conditions is presented in Table 2.

Table 2. Emission of $\mathrm{NO}_{x}, \mathrm{CO}, \mathrm{HC}$ and $\mathrm{CO}_{2}$ in the exhausts of Gulfstream IV in each section of the flight from Gdansk to Rzeszow with the time given

\begin{tabular}{|c|c|c|c|c|c|}
\hline $\begin{array}{c}\text { Section } \\
\text { number }\end{array}$ & $\begin{array}{c}\text { Time } \\
{[\mathrm{min}]}\end{array}$ & $\begin{array}{c}\mathrm{E}_{\mathrm{NOx}} \\
{[\mathrm{kg}]}\end{array}$ & $\begin{array}{c}\mathrm{E}_{\mathrm{CO}} \\
{[\mathrm{kg}]}\end{array}$ & $\begin{array}{c}\mathrm{E}_{\mathrm{HC}} \\
{[\mathrm{kg}]}\end{array}$ & $\begin{array}{c}\mathrm{E}_{\mathrm{CO} 2} \\
{[\mathrm{~kg}]}\end{array}$ \\
\hline 1 & 1.574637905 & 1.582999 & 0.105986 & 0.013626 & 145.2866 \\
\hline 2 & 1.578639338 & 1.587022 & 0.106256 & 0.013660 & 145.6558 \\
\hline 3 & 1.571337020 & 1.579681 & 0.105764 & 0.013597 & 144.9820 \\
\hline 4 & 1.565781952 & 1.574096 & 0.105390 & 0.013549 & 144.4695 \\
\hline 5 & 1.543086659 & 1.551280 & 0.103863 & 0.013353 & 142.3755 \\
\hline 6 & 1.543086659 & 1.551280 & 0.103863 & 0.013353 & 142.3755 \\
\hline 7 & 1.548471227 & 1.556694 & 0.104225 & 0.013399 & 142.8723 \\
\hline 8 & 1.557344963 & 1.565614 & 0.104822 & 0.013476 & 143.6910 \\
\hline 9 & 1.548471227 & 1.556694 & 0.104225 & 0.013399 & 142.8723 \\
\hline 10 & 1.559820329 & 1.568103 & 0.104989 & 0.013498 & 143.9194 \\
\hline 11 & 1.559820329 & 1.568103 & 0.104989 & 0.013498 & 143.9194 \\
\hline 12 & 1.571337020 & 1.579681 & 0.105764 & 0.013597 & 144.9820 \\
\hline 13 & 1.578639338 & 1.587022 & 0.106256 & 0.013660 & 145.6558 \\
\hline 14 & 1.573117508 & 1.581471 & 0.105884 & 0.013613 & 145.1463 \\
\hline 15 & 1.588472899 & 1.596908 & 0.106917 & 0.013746 & 146.5631 \\
\hline 16 & 1.604131018 & 1.612649 & 0.107971 & 0.013881 & 148.0078 \\
\hline Total & 25.06619539 & 25.1993 & 1.687164 & 0.216906 & 2312.774 \\
\hline & & & & & \\
\hline
\end{tabular}

Table 3. Emission of $\mathrm{NO}_{x}, \mathrm{CO}, \mathrm{HC}$ and $\mathrm{CO}_{2}$ in the exhausts of Gulfstream IV in each section of the flight from Rzeszow to Gdansk with the time given

\begin{tabular}{|c|c|c|c|c|c|}
\hline $\begin{array}{l}\text { Section } \\
\text { number }\end{array}$ & $\begin{array}{l}\text { Time } \\
{[\mathrm{min}]}\end{array}$ & $\begin{array}{r}\mathrm{E}_{\mathrm{NOx}} \\
{[\mathrm{kg}]} \\
\end{array}$ & $\begin{array}{l}\mathrm{E}_{\mathrm{CO}} \\
{[\mathrm{kg}]} \\
\end{array}$ & $\begin{array}{l}\mathrm{E}_{\mathrm{HC}} \\
{[\mathrm{kg}]} \\
\end{array}$ & $\begin{array}{l}\mathrm{E}_{\mathrm{CO} 2} \\
{[\mathrm{~kg}]} \\
\end{array}$ \\
\hline 1 & 1.777605428 & 1.787045 & 0.119648 & 0.015382 & 164.0137 \\
\hline 2 & 1.772533398 & 1.781946 & 0.119306 & 0.015338 & 163.5457 \\
\hline 3 & 1.781830968 & 1.791292 & 0.119932 & 0.015419 & 164.4036 \\
\hline 4 & 1.789028314 & 1.798528 & 0.120417 & 0.015481 & 165.0677 \\
\hline 5 & 1.819606298 & 1.829268 & 0.122475 & 0.015746 & 167.8890 \\
\hline 6 & 1.819606298 & 1.829268 & 0.122475 & 0.015746 & 167.8890 \\
\hline 7 & 1.812175506 & 1.821798 & 0.121975 & 0.015681 & 167.2034 \\
\hline 8 & 1.800171323 & 1.809730 & 0.121167 & 0.015577 & 166.0958 \\
\hline 9 & 1.812175506 & 1.821798 & 0.121975 & 0.015681 & 167.2034 \\
\hline 10 & 1.796875136 & 1.806417 & 0.120945 & 0.015549 & 165.7917 \\
\hline 11 & 1.796875136 & 1.806417 & 0.120945 & 0.015549 & 165.7917 \\
\hline 12 & 1.781830968 & 1.791292 & 0.119932 & 0.015419 & 164.4036 \\
\hline 13 & 1.772533398 & 1.781946 & 0.119306 & 0.015338 & 163.5457 \\
\hline 14 & 1.779547029 & 1.788996 & 0.119778 & 0.015399 & 164.1929 \\
\hline 15 & 1.760297703 & 1.769645 & 0.118483 & 0.015232 & 162.4168 \\
\hline 16 & 1.74146036 & 1.750708 & 0.117215 & 0.015069 & 160.6787 \\
\hline Total & 28.61415277 & 28.76609 & 1.925971 & 0.247608 & 2640.132 \\
\hline
\end{tabular}

For comparative purposes, assuming identical external conditions, in Table 3 there are presented the obtained results of the amount of pollutants emitted in the exhaust gases on the return journey (i.e. at the unfavourable wind component vector in this case).

For reference purposes, the results presented in Table 4 were obtained for unreal no wind conditions at the altitude of $10 \mathrm{~km}$.

Table 4. Emission of $\mathrm{NO}_{\mathrm{x}}, \mathrm{CO}, \mathrm{HC}$ and $\mathrm{CO}_{2}$ in the exhausts of Gulfstream IV in each section of the flight from Gdansk to Rzeszow with the time given assuming no wind NO WIND

\begin{tabular}{|c|c|c|c|c|c|}
\hline $\begin{array}{c}\text { Section } \\
\text { number }\end{array}$ & $\begin{array}{c}\text { Time } \\
{[\mathrm{min}]}\end{array}$ & $\begin{array}{c}\mathrm{E}_{\mathrm{NOx}} \\
{[\mathrm{kg}]}\end{array}$ & $\begin{array}{c}\mathrm{E}_{\mathrm{CO}} \\
{[\mathrm{kg}]}\end{array}$ & $\begin{array}{c}\mathrm{E}_{\mathrm{HC}} \\
{[\mathrm{kg}]}\end{array}$ & $\begin{array}{c}\mathrm{E}_{\mathrm{CO} 2} \\
{[\mathrm{~kg}]}\end{array}$ \\
\hline 1 & 1.7 & 1.67884473 & 0.112403379 & 0.014450869 & 154.0832252 \\
\hline 2 & 1.7 & 1.67884473 & 0.112403379 & 0.014450869 & 154.0832252 \\
\hline 3 & 1.7 & 1.67884473 & 0.112403379 & 0.014450869 & 154.0832252 \\
\hline 4 & 1.7 & 1.67884473 & 0.112403379 & 0.014450869 & 154.0832252 \\
\hline 5 & 1.7 & 1.67884473 & 0.112403379 & 0.014450869 & 154.0832252 \\
\hline 6 & 1.7 & 1.67884473 & 0.112403379 & 0.014450869 & 154.0832252 \\
\hline 7 & 1.7 & 1.67884473 & 0.112403379 & 0.014450869 & 154.0832252 \\
\hline 8 & 1.7 & 1.67884473 & 0.112403379 & 0.014450869 & 154.0832252 \\
\hline 9 & 1.7 & 1.67884473 & 0.112403379 & 0.014450869 & 154.0832252 \\
\hline 10 & 1.7 & 1.67884473 & 0.112403379 & 0.014450869 & 154.0832252 \\
\hline 11 & 1.7 & 1.67884473 & 0.112403379 & 0.014450869 & 154.0832252 \\
\hline 12 & 1.7 & 1.67884473 & 0.112403379 & 0.014450869 & 154.0832252 \\
\hline 13 & 1.7 & 1.67884473 & 0.112403379 & 0.014450869 & 154.0832252 \\
\hline 14 & 1.7 & 1.67884473 & 0.112403379 & 0.014450869 & 154.0832252 \\
\hline 15 & 1.7 & 1.67884473 & 0.112403379 & 0.014450869 & 154.0832252 \\
\hline 16 & 1.7 & 1.67884473 & 0.112403379 & 0.014450869 & 154.0832252 \\
\hline Total & 27 & 26.86151569 & 1.798454061 & 0.231213903 & 2465.331603 \\
\hline & & & & & \\
\hline
\end{tabular}

\section{Conclusions}

The aim of the conducted research is to determine the impact of wind on fuel consumption by a passenger jet aircraft during the cruise phase and on emission of pollutants in its engines exhausts. For that purpose, there was assumed a journey between two cities Gdansk and Rzeszow covered by a business jet Gulfstream IV with the velocity of $0.8 \mathrm{Ma}$ at the altitude of $10,000 \mathrm{~m}$.

Based on available real meteorological data, it was possible to take into account the external conditions at the altitude of $10 \mathrm{~km}$ - the wind speed and its direction in relation to the trajectory of the aircraft.

For comparative purposes, to see to what extend the emission of the analysed pollutants is wind dependent, there were considered three scenarios:

I. journey from Gdansk to Rzeszow at the meteorological parameters read from the map presented in Fig. 2;

II. journey from Rzeszow to Gdansk at the meteorological parameters read from the map presented in Fig. 2;

III. journey from Gdansk to Rzeszow at no wind conditions - just to obtain reference results.

The analysis carried out for those scenarios led to the following observations:

1) In general, the higher the headwinds speed, the longer the journey (duration of the flight), and thus the higher the $\mathrm{NO}_{\mathrm{x}}, \mathrm{CO}, \mathrm{HC}$ and $\mathrm{CO}_{2}$ emission values. In the case of tailwind (pushing) winds, the situation is reversed. In the analysed case, the journey from Gdansk to Rzeszow in cruise phase lasted for 25 minutes (Table 2), whereas from Rzeszow to Gdansk - for 29 minutes (Table 3). Such a journey in reference conditions (no wind) would last for 27 minutes (Table 4). 
2) The total emission on a given trajectory is strongly wind dependent:

- In case of the journey from Gdansk to Rzeszow (with favourable winds), the total emission of:
- $\mathrm{NO}_{\mathrm{x}}$ was $25.1993 \mathrm{~kg}$,
- CO was $1.687164 \mathrm{~kg}$,
- $\mathrm{HC}$ was $0.216906 \mathrm{~kg}$,
- $\mathrm{CO}_{2}$ was $2312.774 \mathrm{~kg}$.

- However, on the return trip - from Rzeszow to Gdansk (upwind), the total emission of:
- $\mathrm{NO}_{\mathrm{x}}$ was $28.76609 \mathrm{~kg}$,
- CO was $1.925971 \mathrm{~kg}$,
- $\mathrm{HC}$ was $0.247608 \mathrm{~kg}$,
- $\mathrm{CO}_{2}$ was $2640.132 \mathrm{~kg}$.

- It means that on the analysed route of $384 \mathrm{~km}$ the difference in those emissions depending on the direction of wind impact on the aircraft $\left(\mathrm{V}_{\mathrm{x}}\right)$, in case of:

$$
\begin{aligned}
& \text { - } \mathrm{NO}_{\mathrm{x}} \text { was } 3.6 \mathrm{~kg}, \\
& \text { - } \mathrm{CO} \text { was } 0.3 \mathrm{~kg}, \\
& \text { - } \mathrm{HC} \text { was } 0.03 \mathrm{~kg}, \\
& \text { - } \mathrm{CO}_{2} \text { was } 327.36 \mathrm{~kg} \text {. }
\end{aligned}
$$

- The difference in $\mathrm{CO}_{2}$ emissions results from the fact that on the return journey the aircraft consumed about $100 \mathrm{~kg}$ of fuel more, assuming identical meteorological conditions.

- It can also be noticed an increase in the emission of other pollutants. This results from different emission indexes depended from the engine's operating range (when the engine is running at high load, the $\mathrm{EINO}_{\mathrm{x}}$ emission index is high whereas the EICO and EIHC emission indexes are low).

- It is also worth noting that the percentage differences in emission of all these pollutants in the case of a tailwind flight vs. headwind flight are similar (about 15\%), however, mass differences are significant (e.g. the amount of $\mathrm{CO}_{2}$ emitted compared to the amount of $\mathrm{HC}$ emitted).

Another observation is that in the case of a flight with favourable winds, the total emission is lower compared to the windless variant. In the case of unfavourable winds, which is logical, this emission is higher. It is worth noting that the differences on these 'plus' and 'minus' emissions are not the same (although the wind adopted for analysis has the same value in a given route section but interacts on the aircraft in the opposite direction in relation to its trajectory). These observations are shown in Table 5 and Fig. 4.

Table 5. Total emission of $\mathrm{NO}_{x}, \mathrm{CO}, \mathrm{HC}$ and $\mathrm{CO}_{2}$ in the exhausts of Gulfstream IV in each scenario of the journey

\begin{tabular}{|l|c|c|c|c|}
\hline \multicolumn{1}{|c|}{ Journey scenario } & $\begin{array}{c}\mathrm{ENO}_{\mathrm{x}} \\
{[\mathrm{kg}]}\end{array}$ & $\begin{array}{c}\mathrm{ECO} \\
{[\mathrm{kg}]}\end{array}$ & $\begin{array}{c}\mathrm{EHC} \\
{[\mathrm{kg}]}\end{array}$ & $\begin{array}{c}\mathrm{ECO}_{2} \\
{[\mathrm{~kg}]}\end{array}$ \\
\hline $\begin{array}{l}\text { Headwinds (Gdansk } \\
\text {-Rzeszow journey) }\end{array}$ & 28.7661 & 1.925971 & 0.247608 & 2640.132 \\
\hline $\begin{array}{l}\text { No wind (Gdansk } \\
\text {-Rzeszow or Rzeszow } \\
\text {-Gdansk journey }\end{array}$ & 26.8615 & 1.798454 & 0.231214 & 2465.332 \\
\hline $\begin{array}{l}\text { Tailwinds (Rzeszow } \\
\text {-Gdansk journey) }\end{array}$ & 25.1993 & 1.687164 & 0.216906 & 2312.774 \\
\hline
\end{tabular}

The described research methodology is universal. In the paper it is presented on the example of the Gulfstream IV aircraft due to the access to its technical data, but nothing prevents us from using it for similar analyses for other jet aircraft.

In order to minimize emission of pollutants in the aircraft engines, it may be worth considering to conduct the research on the optimization of the aircraft's flight trajectory, so that it is covered with the most preferable wind direction.

This project has received funding from the SESAR Joint Undertaking under the European Union's Horizon 2020 research and innovation programme under grant agreement No 734129.
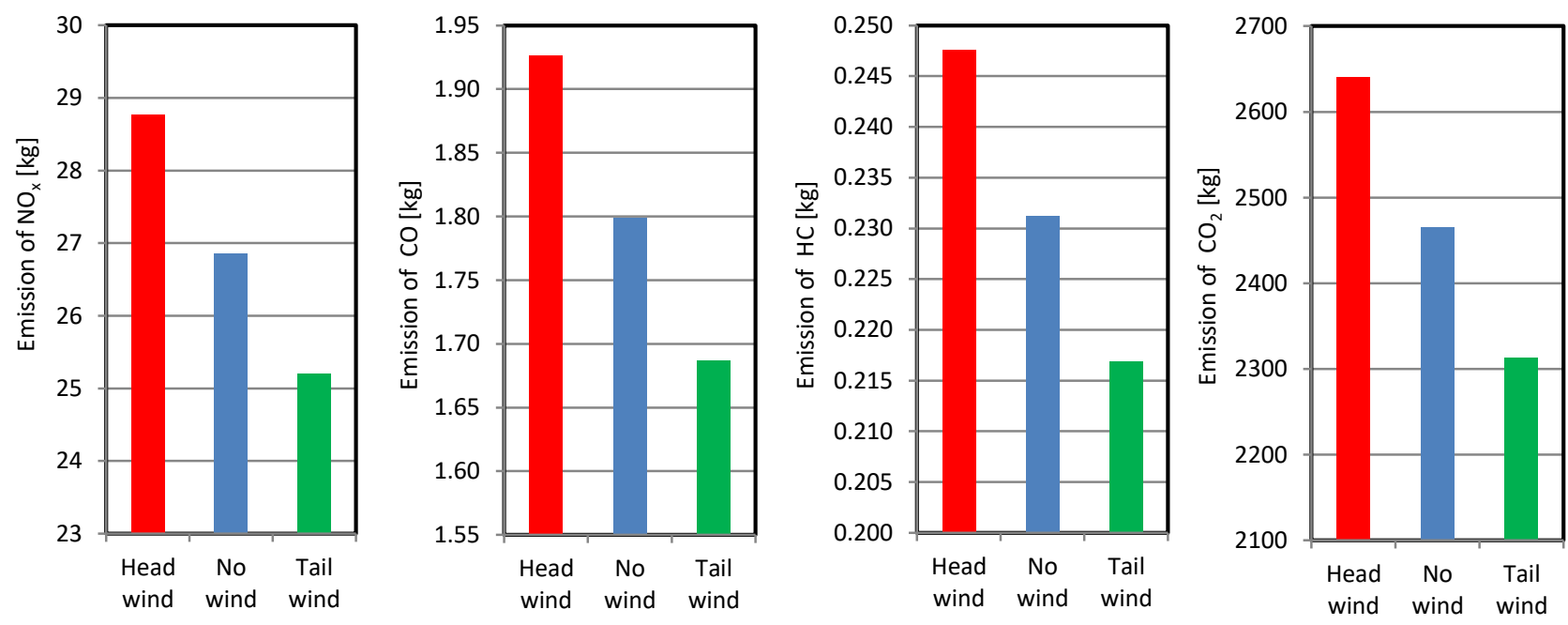

Fig. 4. Total emission of $\mathrm{NO}_{\mathrm{x}}, \mathrm{CO}, \mathrm{HC}$ and $\mathrm{CO}_{2}$ in the exhausts of Gulfstream IV in each scenario of the journey 


\section{Bibliography}

[1] BALMORI, M.A. The effects of microwave radiation on the wildlife. Preliminary results, Valladolid (Spain), 2003.

[2] BRUSOW, W., KLEPACKI, Z., MAJKA, A. Airports and facilities data base. EPATS technical report, Project no. ASA6-CT-2006-044549, 2007.

[3] Clean Sky website. http://www.cleansky.eu

[4] FISZDON, W. Flight mechanics (Mechanika lotu), PWN, Warszawa (in Polish). 1964.

[5] Flightradar website, https://www.flightradar24.com

[6] ICAO aircraft engine emission databank, https://www.easa. europa.eu/easa-and-you/environment/icao-aircraft-engineemissions-databank

[7] International Civil Aviation Organization (ICAO), International Standards and Recommended Practices, Environmental Protection. Annex 16, Volume II Aircraft Engine Emissions (third edition), ICAO, July 2008.
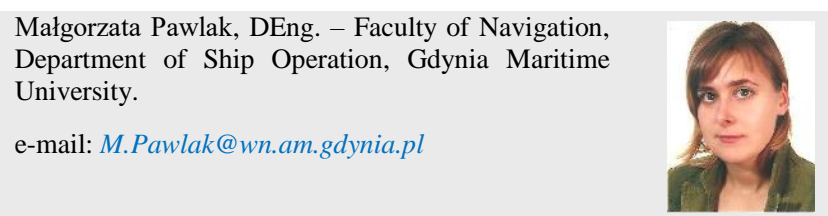

Michał Kuźniar, MEng. - Faculty of Mechanical Engineering and Aeronautics, Rzeszow University of Technology.

e-mail:MKuzniar@prz.edu.pl
[8] IPCC, Revised 1996 Guidelines for National Greenhouse Gas Inventories, Volume 3, Greenhouse Gas Inventory Reference Manual, Intergovernmental Panel on Climate Change, WGI Technical Support Unit, Hadley Centre, Meteorological Office, Bracknell, UK, 1997.

[9] KOPECKI, G., PECCZKOWSKI, M., ROGALSKI, T. Przykładowy algorytm wyznaczania trasy przelotu w przestrzeni lotów swobodnych. Autobusy. 2017, 6.

[10] Maps of meteorological conditions, https://www.windy.com

[11] SCHAEFER, M., BARTOSCH, S. Overview on fuel flow correlation methods for the calculation of $\mathrm{NO}_{\mathrm{x}}, \mathrm{CO}$ and $\mathrm{HC}$ emissions and their implementation into aircraft performance software, Interner Bericht Deutsches Zentrum für Luft- und Raumfahrt (DLR). Institut für Antriebstechnik, Köln. 2013.

[12] SESAR JU website, https://www.sesarju.eu

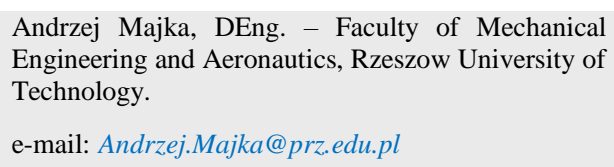

Jowita Pawluczy, MEng. - Faculty of Mechanical Engineering and Aeronautics, Rzeszow University of Technology.

e-mail: Jowita.Pawluczy@prz.edu.pl 